\title{
Genotoxicity of Surface Water Treated With Different Disinfectants Using In Situ Plant Tests
}

\author{
S. Monarca, ${ }^{1}$ M. Rizzoni, ${ }^{2}$ B. Gustavino, ${ }^{2}$ C. Zani, ${ }^{3}$ A. Alberti, ${ }^{3}$ D. Feretti, ${ }^{3}$ \\ and I. Zerbini ${ }^{3}$ \\ 'Department of Hygiene and Public Health, University of Perugia, Italy \\ ${ }^{2}$ Department of Biology, Tor Vergata University, Rome, Italy \\ ${ }^{3}$ Department of Experimental and Applied Medicine, Hygiene Section, \\ University of Brescia, Italy
}

\begin{abstract}
Disinfection of surface drinking water, in particular water chlorination, results in many by-products with potential genotoxic and/or carcinogenic activity. In the present study, we evaluated the genotoxicity of surface water after treatment with different disinfectants by means of in situ plant genotoxicity assays (micronucleus and chromosomal aberration tests) which can detect both clastogenic and aneugenic effects. The study was carried out at a pilot plant using lake water after sedimentation and filtration. This water supplied four stainless steel basins: three basins were disinfected with sodium hypochlorite, chlorine dioxide, and peracetic acid and the fourth basin containing untreated lake water was used as a control. Plants were exposed in situ in the basins. The study was carried out using water collected in different sea-
\end{abstract}

sons over a period of about 1 year in order to assess the treatments in different physical and chemical lake water conditions. The micronucleus test in root cells of Vicia faba (Vicia faba/MCN test) revealed genotoxicity in many samples of disinfected water. The micronucleus test in Tradescantia pollen cells and the chromosome aberration test in root cells of Allium cepa showed genotoxic effects only in some disinfected samples, but also revealed genotoxicity in raw water. The results of the study indicated that the Vicia faba/ MCN test was the most sensitive plant assay for disinfected water and that peracetic acid disinfection produced similar or lower genotoxicity than sodium hypochlorite or chlorine dioxide treatment. Environ. Mol. Mutagen. 41:353-359, 2003. @ 2003 WileyLiss, Inc.

Keywords: genotoxicity; clastogenicity/aneugenicity; Tradescantia/micronuclei test; Allium cepa test; Vicia faba test; water disinfection

\section{INTRODUCTION}

Drinking water disinfection may produce toxic compounds, particularly if the water is obtained from surface sources. Water chlorination results in mutagenic/carcinogenic by-products derived from the reaction of chlorine with organic compounds (humic and fulvic acids) naturally present in water [Rook, 1974; WHO, 1996]. For this reason it is very important to test alternative disinfectants to chlorine in order to reduce these potential health risks. Among the new disinfectants, peracetic acid $\left(\mathrm{CH}_{3}-\mathrm{CO}-\mathrm{OOH}, \mathrm{PAA}\right)$ deserves to be studied for its application in drinking water disinfection, since it is a potent antimicrobial agent and has many applications in hospitals, laboratories, and factories [Baldry et al., 1991, 1995; Lefevre et al., 1992]. More recently, PAA has been found to be an effective biocidal compound for wastewater disinfection, and previous research showed that disinfection of lake and river drinking water with PAA gave rise to a very low level of genotoxicity and produced only carboxylic acids [Monarca et al., 2002a], which are not recognized as mutagenic.

Drinking water has been intensively examined for gene mutations, primarily by assaying extracts of water in bacterial tests, and several studies on different disinfectants have been carried out [Koivusalo et al., 1994; Loper et al., 1980; Monarca 1985, 1998, 2002a; Romero et al., 1992; Tuomisto et al., 1990; Wilcox and Williamson, 1986; Wilcox et al., 1988]. Plant genotoxicity tests measure different genetic endpoints (clastogenicity and aneugenicity) and allow researchers to study water in situ, without requiring lengthy and expensive methods for concentration. Plant tests have recently been used for the detection of mutagens in water [for reviews, see Grant, 1994, 1999]. Vicia faba and Allium cepa have been utilized for environmental waters, disinfected wastewaters, and also drinking water [Chang-Qun et al., 1999; Knasmuller et al., 1998; Minissi

Grant sponsor: the Ministero dell'Università e della Ricerca Scientifica e Tecnologica (40\% funds, MURST, to SM and MR.).

*Correspondence to: Prof. Silvano Monarca, Department of Hygiene and Public Health, University of Perugia, Via del Giochetto, 06100 Perugia, Italy. E-mail: monarca@unipg.it

Received 8 October 2002; provisionally accepted 6 December 2002; and in final form 2 March 2003

DOI 10.1002/em.10161 
and Lombi, 1997; Minissi et al., 1998; Rizzoni et al., 1995; Smaka-Kincl et al., 1996]; more recently, the Tradescantial micronuclei test has been used to detect genotoxicity in concentrated and unconcentrated samples of drinking water [Helma et al., 1994; Monarca et al., 1998, 2002a].

This study was performed as a part of a research program designed to evaluate the influence of different disinfection treatments on the formation of genotoxins in surface water used for human consumption. Different test systems were used for in vivo / in situ exposure to disinfected water (plants, fish, molluscs) and in vitro treatments with water concentrates (human lymphocytes, Salmonella, yeast), detecting different endpoints (genotoxicity, mutagenicity, clastogenicity, and aneugenicity). The results reported describe in situ short-term genotoxicity assays in plants, which, in particular, are able to detect clastogenic and aneugenic effects following in situ exposure to unconcentrated water samples. The study was performed at a pilot drinking water treatment plant using lake water. After sedimentation and filtration, the lake water samples were collected before and after disinfection with different disinfectants: sodium hypochlorite $(\mathrm{NaClO})$, chlorine dioxide $\left(\mathrm{ClO}_{2}\right)$, and PAA. The in situ bioassays employed in this study were the micronucleus test in Tradescantia pollen cells, the chromosomal aberration test, and the toxicity test in root cells of Allium cepa and the micronucleus test in root cells of Vicia faba.

\section{MATERIALS AND METHODS}

\section{Water Source and Treatment}

A pilot drinking water plant supplied with water from Lake Trasimeno in Central Italy was used to compare the effectiveness of different disinfection treatments [Monarca et al., 2002b]. The pilot plant consisted of the following units: 1) a pump to capture lake water; 2) a sedimentation system and two $1 \mathrm{~m}^{3}$ basins to clarify the water; 3) a filtration system with a $50 \mu \mathrm{m}$ stainless filter followed by a $25 \mu \mathrm{m}$ filter cloth to remove suspended solids; 4) a water main that divides into four secondary pipelines to supply four 300-L stainless steel basins (contact basins): three were used for disinfection treatments and one for raw water as control; and 5) four $1 \mathrm{~m}^{3}$ stainless steel basins (exposure basins), which received water flowing from the contact basins and were used for in situ exposure of plants.

The study was conducted over a period of about 1 year in different seasons (October 2000, February 2001, and June 2001) in order to assess the treatments in different physical and chemical lake water conditions.

After sedimentation and filtration, lake water was treated with the different disinfectants. The doses of disinfectants added (mean concentration) were chosen in order to have a maximum of $0.2 \mathrm{mg} / \mathrm{L}$ free disinfectant residue: $1.2 \mathrm{mg} / \mathrm{L}$ of $\mathrm{NaClO}, 1.6 \mathrm{mg} / \mathrm{L}$ of $\mathrm{ClO}_{2}$, and $1 \mathrm{mg} / \mathrm{L}$ of PAA in the October 2000 Experiment; $0.7 \mathrm{mg} / \mathrm{L}$ of $\mathrm{NaClO}, 1.6 \mathrm{mg} / \mathrm{L}$ of $\mathrm{ClO}_{2}$, and 0.6 $\mathrm{mg} / \mathrm{L}$ of PAA in the February 2001 Experiment; and $0.6 \mathrm{mg} / \mathrm{L}$ of $\mathrm{NaClO}$, $1.8 \mathrm{mg} / \mathrm{L}$ of $\mathrm{ClO}_{2}$, and $0.9 \mathrm{mg} / \mathrm{L}$ of PAA in the June 2001 Experiment.

\section{Physical and Chemical Parameters}

Total organic carbon (TOC), UV absorbance at $254 \mathrm{~nm}$, disinfectant demand, and total trihalomethane formation potential (TTHMFP) [APHA, 1998] were determined before each experiment. During the experiments, water temperature, turbidity, $\mathrm{pH}$, redox potential, and dissolved $\mathrm{O}_{2}$ were monitored in both disinfected and raw water. In addition, free disinfectant residues were monitored in disinfected water [Monarca et al., 2002b].

Raw and disinfected waters were concentrated by adsorption on $\mathrm{C}_{18}$ silica cartridges, according to the U.S. Environmental Protection Agency 525.2 method [US EPA, 1994] with some modifications [Monarca et al., 2002a]. The concentrates were analyzed for mutagenicity using the Ames test [Monarca et al., 2002c] and for disinfection by-products using gas chromatography / mass spectrometry (GC/MS) [Monarca et al., 2002a].

\section{Plant Genotoxicity Tests}

Raw and disinfected waters were analyzed by means of in situ exposure with three plant genotoxicity tests: the Tradescantia/micronucleus test in pollen cells of Tradescantia, the anaphase chromosomal aberration test in Allium cepa roots germinated directly in the water samples, and the micronucleus test in secondary roots of Vicia faba. The micronucleus tests and the chromosomal aberration test are able to detect both clastogenic and aneugenic effects. The assays were performed by exposing the plants (Tradescantia, Allium cepa, and Vicia faba) directly to disinfected water samples in stainless steel basins for 6 and $72 \mathrm{hr}$. The genotoxic effect was evaluated by comparing the disinfected waters both with raw water, to detect the specific contribution of the disinfection by-products, and with physiological solutions or mineral waters, to detect the overall effect of disinfection by-products and raw water. A positive control was included with each assay.

\section{Tradescantia/Micronucleus (TRAD/MCN) Test}

The Tradescantia/micronucleus test (TRAD/MCN test) was performed using Tradescantia clone \#4430, a hybrid between $T$. hirsutiflora and $T$. subacaulis [Ma et al., 1994]. Young Tradescantia inflorescences were immersed directly in the water in the four basins for $6 \mathrm{hr}$. After exposure the inflorescences were maintained in mineral water for a further $48 \mathrm{hr}$ of recovery time, then fixed following standard protocols. Mineral water was used as a negative control. The buds were then used to prepare slides and the micronucleus frequency in meiotic pollen mother cells was evaluated [Ma et al., 1994]. The data were expressed as micronuclei/100 tetrads and were statistically analyzed by analysis of variance, and the 0.05 level of significance between the raw water and disinfected water groups was determined by Dunnett's test. The statistical significance also was studied for raw and treated water samples compared to the negative control. A positive control with $5 \mathrm{mg} / \mathrm{L}$ of maleic hydrazide was performed concurrently.

\section{Allium cepa Test}

Equal-sized (2-2.5 cm in diameter) young bulbs of Allium cepa were exposed to disinfected and raw water for $72 \mathrm{hr}$. After exposure the roots were cut and fixed following standard protocols. Clastogenicity as anaphase chromosomal aberrations (bridges, lagging chromosomes, and fragments) was determined in root cells [Fiskesjo, 1985]. The mitotic index was also evaluated. At least 800 anaphasic cells per sample were scored for chromosomal aberrations and 5,000 cells per sample were scored for the mitotic index. The length of roots was used as an index of toxicity and modifications in root form and consistency were observed [Rank and Nielsen, 1994]. Data analysis was performed by means of the $\chi^{2}$ test. The frequency of chromosomal aberrations and mitotic index values for disinfected waters were compared to those of raw water to determine the effect of the disinfectants. Raw and treated waters were also compared to a negative control (mineral water stored in glass). A positive control was performed with maleic hydrazide $(10 \mathrm{mg} / \mathrm{L})$ to ensure the effectiveness of the assay. 
TABLE I. Physical and Chemical Analyses of Disinfected and Raw Lake Water

\begin{tabular}{|c|c|c|c|c|}
\hline Parameters & Raw water & $\mathrm{ClO}_{2}$ & $\mathrm{NaClO}$ & PAA \\
\hline \multicolumn{5}{|c|}{ October Experiment } \\
\hline Temperature $\left({ }^{\circ} \mathrm{C}\right)$ & 16.4 & & & \\
\hline $\mathrm{UV}_{254 \mathrm{~nm}}$ & 0.092 & 0.431 & 0.352 & 0.249 \\
\hline TOC (mg/L) & 6.4 & 7.6 & 6.4 & 6.8 \\
\hline THM $(\mu \mathrm{g} / \mathrm{L})$ & $<0.10$ & $<0.10$ & 1.24 & $<0.10$ \\
\hline $\mathrm{AOX}(\mu \mathrm{g} / \mathrm{L})$ & 39 & 44 & 56 & 43 \\
\hline $\begin{array}{l}\text { Potential formation THM } \\
(\mu \mathrm{g} / \mathrm{L})\end{array}$ & 126.3 & & & \\
\hline \multicolumn{5}{|c|}{ February Experiment } \\
\hline Temperature $\left({ }^{\circ} \mathrm{C}\right)$ & 10.1 & & & \\
\hline $\mathrm{UV}_{254 \mathrm{~nm}}$ & 0.163 & 0.188 & 0.185 & 0.172 \\
\hline TOC (mg/L) & 9.4 & 8.7 & 9.5 & 9.5 \\
\hline THM $(\mu \mathrm{g} / \mathrm{L})$ & $<0.10$ & $<0.10$ & 9.3 & $<0.10$ \\
\hline $\operatorname{AOX}(\mu \mathrm{g} / \mathrm{L})$ & 12 & 15 & 43 & 13 \\
\hline $\begin{array}{l}\text { Potential formation THM } \\
(\mu \mathrm{g} / \mathrm{L})\end{array}$ & 158 & & & \\
\hline \multicolumn{5}{|c|}{ June Experiment } \\
\hline Temperature $\left({ }^{\circ} \mathrm{C}\right)$ & 24.6 & & & \\
\hline $\mathrm{UV}_{254 \mathrm{~nm}}$ & 0.67 & 0.62 & 0.60 & 0.61 \\
\hline TOC (mg/L) & 5.8 & 6.0 & 5.9 & 5.9 \\
\hline THM ( $\mu \mathrm{g} / \mathrm{L})$ & $<0.10$ & $<0.10$ & 1.34 & $<0.10$ \\
\hline $\mathrm{AOX}(\mu \mathrm{g} / \mathrm{L})$ & 8 & 12 & 39 & 10 \\
\hline $\begin{array}{l}\text { Potential formation THM } \\
(\mu \mathrm{g} / \mathrm{L})\end{array}$ & 475 & & & \\
\hline
\end{tabular}

\section{Vicia faba Micronucleus Test (Vicia faba/MCN test)}

The micronucleus test was performed in the secondary root tips of Vicia faba, following standard protocols [Degrassi and Rizzoni, 1982]. Vicia faba secondary roots were exposed to disinfected waters for 6 and $72 \mathrm{hr}$. The roots exposed for $6 \mathrm{hr}$ were then placed for $66 \mathrm{hr}$ in the raw water basin, up to fixation, whereas negative control (Hoagland's solution) and raw lake water exposures were performed for $72 \mathrm{hr}$. The continuous $72-\mathrm{hr}$ treatment allowed an evaluation of the equilibrium frequency of micronuclei after a long-term exposure. All the roots were fixed in 1:3 acetic acid-ethanol after $72 \mathrm{hr}$ from the beginning of exposure. The frequency of micronuclei in secondary roots was then determined in cut and squashed tips after Feulgen staining. The frequency of micronuclei was evaluated in $5 \times 10^{4}$ cells and the data were analyzed according to Dunn's multiple comparison test. The micronucleus frequencies of the roots exposed to disinfected and raw waters were compared and both of these values were compared to that of the roots exposed to Hoagland's physiological solution. A positive control with maleic hydrazide $(10 \mathrm{mg} / \mathrm{L}$ for $6 \mathrm{hr})$ was also performed.

\section{RESULTS}

The results of the physical and chemical analyses carried out on raw and disinfected lake water sampled in October 2000 and in February and June 2001 are shown in Table I. Chemical analyses showed high concentrations of TOC in the raw lake water $(5.8-9.5 \mathrm{mg} / \mathrm{L})$, whereas $\mathrm{UV}_{254}$ absorbances were $0.092 \mathrm{abs} / \mathrm{cm}$ in October, $0.163 \mathrm{abs} / \mathrm{cm}$ in February, and $0.670 \mathrm{abs} / \mathrm{cm}$ in June. TTHMFP in raw water
TABLE II. Mean Frequency of Micronuclei in Early Tetrads of Tradescantia Inflorescences Exposed to Raw and Treated Lake Water for $6 \mathrm{hr}$ Followed by $48 \mathrm{hr}$ of Recovery Time

\begin{tabular}{|c|c|c|}
\hline Experiment & $\begin{array}{c}\text { Disinfection } \\
\text { treatments } \\
(\mathrm{mg} / \mathrm{L})\end{array}$ & $\begin{array}{c}\text { MCN/100 tetrads } \\
\text { (mean } \pm \text { standard deviation) }\end{array}$ \\
\hline \multirow[t]{5}{*}{ October Experiment } & Negative control & $0.8 \pm 0.2$ \\
\hline & Raw water & $2.2 \pm 1.4^{*}$ \\
\hline & $\mathrm{ClO}_{2}(1.6 \mathrm{mg} / \mathrm{L})$ & $3.0 \pm 0.4^{*}$ \\
\hline & $\mathrm{NaClO}(1.2 \mathrm{mg} / \mathrm{L})$ & $2.0 \pm 0.7^{*}$ \\
\hline & PAA $(1 \mathrm{mg} / \mathrm{L})$ & $6.3 \pm 1.3^{* * \text { оo }}$ \\
\hline \multirow[t]{5}{*}{ February Experiment } & Negative control & $0.9 \pm 0.6$ \\
\hline & Raw water & $3.8 \pm 1.5^{*}$ \\
\hline & $\mathrm{ClO}_{2}(1.6 \mathrm{mg} / \mathrm{L})$ & $8.0 \pm 0.8^{* * \text { оо }}$ \\
\hline & $\mathrm{NaClO}(0.7$ mg/L) & $4.9 \pm 1.9 * *$ \\
\hline & PAA $(0.6$ mg/L) & $4.3 \pm 2.8^{* *}$ \\
\hline \multirow[t]{5}{*}{ June Experiment } & Negative control & $2.3 \pm 1.2$ \\
\hline & Raw water & $3.8 \pm 1.5$ \\
\hline & $\mathrm{ClO}_{2}(1.8 \mathrm{mg} / \mathrm{L})$ & $6.7 \pm 3.6^{*}$ \\
\hline & $\mathrm{NaClO}(0.6$ mg/L) & $4.2 \pm 1.2$ \\
\hline & PAA $(0.9 \mathrm{mg} / \mathrm{L})$ & $5.0 \pm 3.2$ \\
\hline
\end{tabular}

${ }^{\text {oo }}$ Statistically significant vs. raw water according to Dunnett's test $(P<$ $0.01)$.

* Statistically significant vs. negative control according to Dunnett's test $(P<0.05)$.

**Statistically significant vs. negative control according to Dunnett's test $(P<0.01)$.

Positive control: maleic hydrazide $(5 \mathrm{mg} / \mathrm{L}), 15.4 \pm 2.8$.

was $126 \mu \mathrm{g} / \mathrm{L}, 158 \mu \mathrm{g} / \mathrm{L}$, and $475 \mu \mathrm{g} / \mathrm{L}$ in October, February, and June, respectively.

At the doses added in the pilot plant, only $\mathrm{NaClO}$ produced low levels of THM. However, $\mathrm{NaClO}$ did react with the high level of organic substances to form unknown organochlorinated compounds. AOX concentration increased only in NaClO-disinfected water, especially in the February and June experiments, whereas AOX remained similar to those found in raw water after $\mathrm{ClO}_{2}$ and PAA treatment.

GC/MS analyses of concentrates revealed the formation of several by-products, some of them genotoxic, derived from disinfection with $\mathrm{NaClO}$ (bromoform, 5-methyl-2furancarboxyaldehyde, 3-acetyl-dihidro-2 $(3 \mathrm{H})$ furanone, dichloroacetic acid, and dibromoacetic acid) and $\mathrm{ClO}_{2}$ (hexanal, butyl acetate, 2-furancarboxaldehyde, bromoform, heptanal, 1,1-dibromopropanone, 4,4-dibromo-2-butanone, 5-methyl-2-furancarboxyaldehyde, octanal, 1,4-dichlorobenzene, bromotoluene, nonanal, dodecanoic acid, decanoic acid, and dibromoacetic acid). A lesser number of byproducts were found in PAA-disinfected water (1-methoxy4-methylbenzene, nonanal, and decanal).

These concentrates were always negative when analyzed using the Ames test at doses up to 3-L equivalents per plate [Monarca et al., 2002c].

The results of the TRAD/MCN test performed on raw and disinfected lake water are shown in Table II. During the 
TABLE III. Anaphase Aberrations and Mitotic Index in Allium cepa Exposed for $72 \mathrm{hr}$ to Raw and Treated Lake Water

\begin{tabular}{lllc}
\hline Experiment & \multicolumn{1}{c}{$\begin{array}{c}\text { Disinfection } \\
\text { treatments } \\
(\mathrm{mg} / \mathrm{L})\end{array}$} & $\begin{array}{c}\text { Anaphase } \\
\text { aberrations } \\
(\%)\end{array}$ & $\begin{array}{c}\text { Mitotic } \\
\text { index } \\
(\%)\end{array}$ \\
\hline October Experiment & Negative control & 0.6 & 5.0 \\
& Raw water & $2.4^{*}$ & 5.7 \\
& $\mathrm{ClO}_{2}(1.6 \mathrm{mg} / \mathrm{L})$ & $3.0^{* *}$ & 4.5 \\
& $\mathrm{NaClO}(1.2 \mathrm{mg} / \mathrm{L})$ & $3.6^{* * *}$ & 5.6 \\
& $\mathrm{PAA}(1 \mathrm{mg} / \mathrm{L})$ & $2.9^{* * *}$ & 5.4 \\
\hline \multirow{3}{*}{ February Experiment } & $\mathrm{Negative} \mathrm{control}$ & 2.0 & 6.0 \\
& $\mathrm{Raw}$ water & 0.5 & 5.9 \\
& $\mathrm{ClO}(1.6 \mathrm{mg} / \mathrm{L})$ & $2.5^{\circ}$ & 5.8 \\
& $\mathrm{NaClO}(0.7 \mathrm{mg} / \mathrm{L})$ & 1.4 & 5.4 \\
& $\mathrm{PAA}(0.6 \mathrm{mg} / \mathrm{L})$ & 1.1 & 5.1 \\
\hline \multirow{3}{*}{ June Experiment } & $\mathrm{Negative} \mathrm{control}$ & 1.7 & 6.4 \\
& $\mathrm{Raw}$ water & 1.7 & 6.8 \\
& $\mathrm{ClO}(1.8 \mathrm{mg} / \mathrm{L})$ & 2.7 & 7.0 \\
& $\mathrm{NaClO}(0.6 \mathrm{mg} / \mathrm{L})$ & 2.3 & 8.0 \\
& $\mathrm{PAA}(0.9 \mathrm{mg} / \mathrm{L})$ & 1.5 & 8.2 \\
\hline
\end{tabular}

${ }^{\circ}$ Statistically significant vs. raw water according to $\chi^{2}$ test $(P<0.05)$. * Statistically significant vs. negative control according to $\chi^{2}$ test $(P<$ 0.05).

** Statistically significant vs. negative control according to $\chi^{2}$ test $(P<$ $0.01)$.

***Statistically significant vs. negative control according to $\chi^{2}$ test $(P<$ 0.001).

Positive control: maleic hydrazide $(10 \mathrm{mg} / \mathrm{L}), 5.9 \pm 4.1$ for anaphase aberrations and $2.5 \pm 1.0$ for the mitotic index.

October Experiment this test showed an increase in the frequency of micronuclei only for the PAA treatment in comparison with the raw water, but all samples gave an increase of micronucleus frequency in comparison with the negative control (mineral water), thus revealing clastogenic and aneugenic activity in raw water. In the February Experiment the $\mathrm{ClO}_{2}$ treatment produced a significant increase in micronucleus frequency in treated water vs. raw water. Again, all the samples were genotoxic in comparison with the negative control. In the June Experiment $\mathrm{ClO}_{2}$ treatment produced an increase in micronuclei only vs. the negative control. The other disinfectant treatments did not increase micronucleus frequency in comparison to either raw water or the negative control.

The Allium cepa test gave negative results for all disinfectants in the October Experiment (Table III). All water samples were positive vs. the negative control only, not vs. raw water. In the February Experiment the genotoxicity of the $\mathrm{ClO}_{2}$-treatment was confirmed, but in the June Experiment none of the disinfectants induced anaphase chromosomal aberrations. Although the mitotic index was always more than $1 \%$, indicating that the cellular division rate was not influenced by the disinfection treatments (data not shown), the length of the roots for all the test plants was shorter than the negative controls. Other signs of toxicity, such as changes in form and consistency, were present in the roots, particularly in those exposed to raw water. This toxicity was noted at all sampling times.

The results of the Vicia faba/MCN test are shown in Table IV. An increase in the frequency of micronuclei was found in secondary roots exposed to disinfected water in comparison with those exposed to raw water in all the experiments, with some remarkable patterns. For the October and June experiments, 72-hr exposures to disinfected waters gave higher micronucleus frequencies compared to the corresponding values obtained after 6-hr exposures. These results can be explained by assuming a progressive reduction of micronucleus frequency after 6-hr exposure due to dilution of micronuclei through successive mitoses after the initial induction, while micronucleus frequencies after 72-hr exposures have reached an equilibrium value between dilution and de novo induction. The results of the February Experiment showed little difference between 6-hrand 72-hr-treatments, which may be due to the longer cell cycle owing to low water temperature. Because of the low temperature, the expected reduction in the frequency of micronuclei after the 6-hr treatment may not have taken place. There was no significant difference in micronucleus frequency between roots exposed to raw water or to Hoagland's solution in any season; therefore, a clastogenic/aneugenic effect of raw water can be ruled out and these effects are only due to disinfection by-products. NaClO-disinfected water had the strongest clastogenic/aneugenic effect in all the seasons, $\mathrm{ClO}_{2}$-disinfected water had a lower effect in all the seasons, and PAA had a weak effect only in the October Experiment.

\section{DISCUSSION}

The aims of the present research were to study the formation of genotoxic/carcinogenic disinfection by-products in disinfected surface drinking water by means of in vivo short-term plant genotoxicity tests and to compare the effects of two widely used disinfectants, $\mathrm{NaClO}$ and $\mathrm{ClO}_{2}$, with a new disinfectant, PAA. The pilot drinking water plant allowed the in situ concurrent exposure of different plants to water treated with different disinfectants. The experiments were carried out in different seasons in order to evaluate the influence of changes in the chemical characteristics of the water on genotoxicity.

Many technical problems were solved before and during the experiment, particularly relating to the addition of the disinfectant solutions and the monitoring of free disinfectants to minimize toxic effects. The concentrations of the disinfectants were changed slightly during the experiments due to variations in disinfectant demand and this fact may have influenced the results. During the winter period, Allium cepa experienced reduced root growth because of the low temperature.

Table V shows a summary of the plant clastogenicity/ 
TABLE IV. Mean Frequency $( \pm \mathrm{SE})$ of Micronuclei/1,000 Cells in Root Tip Cells of Vicia faba Exposed to Raw and Treated Lake Water, Evaluated in 10 Root Tips, 5,000 Cells per Tip

\begin{tabular}{|c|c|c|c|}
\hline \multirow[b]{3}{*}{ Experiment } & \multirow{3}{*}{$\begin{array}{l}\text { Disinfection treatments } \\
(\mathrm{mg} / \mathrm{L})\end{array}$} & \multicolumn{2}{|c|}{$\mathrm{MCN}$} \\
\hline & & \multicolumn{2}{|c|}{ Exposure time } \\
\hline & & 6 hours & 72 hours \\
\hline October Experiment & $\begin{array}{l}\text { Negative control } \\
\text { (Hoagland's solution) } \\
\text { Raw water } \\
\mathrm{ClO}_{2}(1.6 \mathrm{mg} / \mathrm{L}) \\
\mathrm{NaClO}(1.2 \mathrm{mg} / \mathrm{L}) \\
\text { PAA }(1 \mathrm{mg} / \mathrm{L})\end{array}$ & $\begin{aligned} 0.88 & \pm 0.13 \\
1.2 & \pm 0.22 \\
1.52 & \pm 0.26^{\circ *}\end{aligned}$ & $\begin{array}{l}0.38 \pm 0.1 \\
0.54 \pm 0.11 \\
1.48 \pm 0.21^{\circ *} \\
3.08 \pm 0.27^{\circ 00 * * *} \\
1.08 \pm 0.16\end{array}$ \\
\hline February Experiment & $\begin{array}{l}\text { Negative control } \\
\text { (Hoagland's solution) } \\
\text { Raw water } \\
\mathrm{ClO}_{2}(1.6 \mathrm{mg} / \mathrm{L}) \\
\mathrm{NaClO}(0.7 \mathrm{mg} / \mathrm{L}) \\
\text { PAA }(0.6 \mathrm{mg} / \mathrm{L})\end{array}$ & $\begin{aligned} 1.42 & \pm 0.11^{\mathrm{ooo} * * *} \\
1.68 & \pm 0.21^{\mathrm{ooo} * * *} \\
0.9 & \pm 0.1\end{aligned}$ & $\begin{array}{l}0.32 \pm 0.08 \\
0.34 \pm 0.09 \\
1.38 \pm 0.12^{\text {ooo*** }} \\
1.68 \pm 0.18^{\text {ooo*** }} \\
1.04 \pm 0.08\end{array}$ \\
\hline June Experiment & $\begin{array}{l}\text { Negative control } \\
\quad \text { (Hoagland's solution) } \\
\text { Raw water } \\
\mathrm{ClO}_{2}(1.8 \mathrm{mg} / \mathrm{L}) \\
\mathrm{NaClO}(0.6 \mathrm{mg} / \mathrm{L}) \\
\text { PAA }(0.9 \mathrm{mg} / \mathrm{L})\end{array}$ & $\begin{array}{l}0.74 \pm 0.11 \\
1.12 \pm 0.1 \\
0.76 \pm 0.11\end{array}$ & $\begin{aligned} 0.6 & \pm 0.13 \\
0.42 & \pm 0.11 \\
1.34 & \pm 0.26^{\circ} \\
2.2 & \pm 0.53^{\mathrm{oo} *} \\
1.06 & \pm 0.17\end{aligned}$ \\
\hline
\end{tabular}

${ }^{\circ}$ Statistically significant vs. raw water according to Dunn's Multiple Comparison Test $(P<0.05)$.

${ }^{\circ}$ Statistically significant vs. raw water according to Dunn's Multiple Comparison Test $(P<0.01)$.

${ }^{\circ o o}$ Statistically significant vs. raw water according to Dunn's Multiple Comparison Test $(P<0.001)$.

*Statistically significant vs. negative control according to Dunn's Multiple Comparison Test $(P<0.05)$.

***Statistically significant vs. negative control according to Dunn's Multiple Comparison Test $(P<0.001)$.

Positive control: maleic hydrazide $(10 \mathrm{mg} / \mathrm{L})$ for $6 \mathrm{hr}, 25.7 \pm 14.3$.

aneugenicity results. All the disinfectant treatments induced a clastogenic/aneugenic effect in plant cells, which was particularly evident for $\mathrm{ClO}_{2}$ - and $\mathrm{NaClO}$-disinfected water. However, it should be pointed out that the raw water was also positive in some of the tests. $\mathrm{ClO}_{2}$ - and $\mathrm{NaClO}$-disinfected waters produced higher clastogenic/aneugenic responses than PAA-treated water. This finding is in agreement with data from GC/MS analyses of concentrates, which revealed the formation of several by-products, some of them genotoxic, derived from disinfection with $\mathrm{NaClO}$ and $\mathrm{ClO}_{2}$ [Monarca et al., 2002a]. The values of AOX and THM increased only in NaClO-disinfected waters (Table I). The results show that PAA produced similar or even lower water genotoxic effects in comparison with the other disinfectants. This biocide, considered a good disinfectant for wastewater disinfection [Baldry et al., 1991, 1995; Lefevre et al., 1992], showed lower bactericidal properties than those found for $\mathrm{NaClO}$ and $\mathrm{ClO}_{2}$ in previous experiments carried out at a drinking water pilot plant [Monarca et al., 2002a]. Therefore, additional experiments with higher doses should be carried out to better evaluate the applicability of PAA for drinking water disinfection.

It should be pointed out that the genotoxicity found in these experiments could be due not only to the presence of disinfection by-products, but also to the free disinfectants still present in the disinfected surface water. In fact, previous tests indicate that the pure disinfectants dissolved in distilled water are genotoxic in plants [Monarca et al., 2002d].

In conclusion, the pilot plant allowed us to evaluate the effects of different disinfectants on the same water by means of in situ genotoxicity plant tests for chromosomal aberrations and micronuclei. This approach could be useful as a supporting system to evaluate the potential health hazards caused by the drinking water disinfection processes. These tests seem to be particularly suitable to study genotoxicity of disinfected drinking water and show some advantages over bacterial tests. Plant tests do not need water concentration steps, they can be used in full-scale treatment plants for in situ continuous monitoring of disinfection by-products and they are able to analyze both volatile and nonvolatile compounds concurrently present in disinfected water. The negative results obtained in the Ames test using the same disinfected waters after concentration may be due to the different genetic endpoint (gene mutation) and to the absence of volatile compounds in the water concentrates. Among the plant genotoxicity tests, the Vicia faba/MCN test showed the highest sensitivity for water disinfection products, particularly with the longer exposure time (72 hr). Micronucleus frequencies observed in the roots treated with 
TABLE V. Results of Plant Genotoxicity Tests

\begin{tabular}{|c|c|c|c|c|}
\hline \multirow{3}{*}{$\begin{array}{l}\text { Disinfection } \\
\text { treatments }(\mathrm{mg} / \mathrm{L})\end{array}$} & \multirow{3}{*}{$\frac{\begin{array}{c}\text { Tradescantial } \\
\text { MCN test }\end{array}}{\frac{\text { Hours of exposure }}{6}}$} & \multirow{3}{*}{$\begin{array}{c}\text { Allium cepa } \\
\text { anaphase aberration assay } \\
\text { Hours of exposure } \\
72 \\
\end{array}$} & \multirow{2}{*}{\multicolumn{2}{|c|}{$\begin{array}{c}\begin{array}{c}\text { Vicia faba MCN } \\
\text { test }\end{array} \\
\begin{array}{c}\text { Hours of } \\
\text { exposure }\end{array} \\
\end{array}$}} \\
\hline & & & & \\
\hline & & & 6 & 72 \\
\hline \multicolumn{5}{|c|}{ October Experiment } \\
\hline Raw water & $+^{\mathrm{b}}$ & $+^{\mathrm{b}}$ & - & - \\
\hline $\mathrm{ClO}_{2}(1.6 \mathrm{mg} / \mathrm{L})$ & $++^{\mathrm{b}}$ & $++^{\mathrm{b}}$ & - & $++^{a, b}$ \\
\hline $\mathrm{NaClO}(1.2 \mathrm{mg} / \mathrm{L})$ & $+{ }^{\mathrm{b}}$ & $++^{\mathrm{b}}$ & - & $+^{\mathrm{a}, \mathrm{b}}$ \\
\hline PAA $(1 \mathrm{mg} / \mathrm{L})$ & $++^{\mathrm{a}, \mathrm{b}}$ & $++^{\mathrm{b}}$ & $+^{\mathrm{a}, \mathrm{b}}$ & - \\
\hline \multicolumn{5}{|c|}{ February Experiment } \\
\hline Raw water & $+^{\mathrm{b}}$ & - & - & - \\
\hline $\mathrm{ClO}_{2}(1.6 \mathrm{mg} / \mathrm{L})$ & $+^{\mathrm{a}, \mathrm{b}}$ & $+^{\mathrm{a}}$ & $+^{\mathrm{a}, \mathrm{b}}$ & $+^{\mathrm{a}, \mathrm{b}}$ \\
\hline $\mathrm{NaClO}(0.7 \mathrm{mg} / \mathrm{L})$ & $+^{\mathrm{b}}$ & - & $+^{\mathrm{a}, \mathrm{b}}$ & $+^{\mathrm{a}, \mathrm{b}}$ \\
\hline PAA $(0.6 \mathrm{mg} / \mathrm{L})$ & $++^{\mathrm{b}}$ & - & - & - \\
\hline \multicolumn{5}{|c|}{ June Experiment } \\
\hline Raw water & - & - & - & - \\
\hline $\mathrm{ClO}_{2}(1.8 \mathrm{mg} / \mathrm{L})$ & $++^{\mathrm{b}}$ & - & - & $++^{\mathrm{a}}$ \\
\hline $\mathrm{NaClO}(0.6 \mathrm{mg} / \mathrm{L})$ & - & - & - & $+^{\mathrm{a}, \mathrm{b}}$ \\
\hline PAA $(0.9 \mathrm{mg} / \mathrm{L})$ & - & - & - & - \\
\hline
\end{tabular}

$+=$ genotoxic. ${ }^{\mathrm{a} C o m p a r e d}$ to raw water. ${ }^{\mathrm{b}}$ Compared to negative control. $-=$ not genotoxic.

disinfected waters were frequently higher than both control and raw water values. The relative genotoxic effect was comparable to that resulting from exposure to $2-8 \mathrm{cGy}$ of X-rays [Gustavino et al., 1987; Rizzoni et al., 1987].

\section{ACKNOWLEDGMENTS}

We thank Solvay Chimica Italia S.p.A. (Rosignano, LI, Italy) and Promox S.r.l. (Leggiuno, VA, Italy) for technical and financial support. We also thank the other MURST Research Group members: Licia Guzzella, IRSA - CNR, Brugherio (MI); Laura Marabini and Enzo Chiesara, University of Milan, Department of Pharmacology; Giorgio Cantelli-Forti, Moreno Paolini, Patrizia Hrelia and Francesca Maffei, University of Bologna, Department of Pharmacology; Carlo Rossi, Annamaria Buschini, Paola Poli and Luca Pasini, University of Parma, Institute of Genetics; Maria Illuminata Taticchi, Luciana Mantilacci, Concetta Elia and Martin Doerr, University of Perugia, Department of Animal Biology and Ecology; Claudia Bolognesi, National Institute on Cancer Research, Genoa; Augusto Morosi, Donatella Bartoli, Elisabetta Ciccarelli and Margherita di Brizio, ARPA Umbria, Perugia; Susan Richardson and Al Thurston, U.S. Environmental Protection Agency, Athens, GA, USA.

\section{REFERENCES}

APHA. 1998. Standard methods for the examination of water and wastewater, 20th ed. Washington, DC: American Public Health Association. p 5-18/5-68.
Baldry MGC, French MS, Slater D. 1991. The activity of peracetic acid on sewage indicator bacteria and viruses. Wat Sci Technol 24:353357.

Baldry MGC, Cavadore A, French MS, Massa G, Rodrigues LM, Schirch PFT, Threadgold TL. 1995. Effluent disinfection in warm climates with peracetic acid. Wat Sci Technol 31:161-164.

Chang-Qun D, Bin H, Xiao-Hua J, Chuan-hao W, Zenghong W, Ying-Xue W. 1999. Genotoxicity of water samples from Dianchi lake detected by the Vicia faba micronucleus test. Mutat Res 426:121-125.

Degrassi F, Rizzoni M. 1982. Micronucleus test in Vicia faba root tips to detect mutagen damage in fresh-water pollution. Mutat Res 97:1933.

Fiskesjo G. 1985. The Allium test as a standard in environmental monitoring. Hereditas 102:99-112.

Grant WF. 1994. The present status of higher plant bioassays for the detection of environmental mutagens. Mutat Res 310:175-185.

Grant WF. 1999. Higher plant assays for the detection of chromosomal aberrations and gene mutations - a brief historical background on their use for screening and monitoring environmental chemicals. Mutat Res 426:107-112.

Gustavino B, Vitagliano E, Sottili A, Rizzoni M. 1987. A comparison between short-term evolution of micronuclei induced by X-rays and colchicine in root tips of Vicia faba. Mutat Res 192:109-119.

Helma C, Sommer R, Schulte-Hermann R, Knasmuller S. 1994. Enhanced clastogenicity of contaminated groundwater following UV irradiation detected by the Tradescantia micronucleus assay. Mutat Res 323:93-98.

Knasmuller S, Helma C, Eckl PM, Gottmann E, Steinkellner H, Kass Haider T, Parzefall W, Schulte-Hermann R. 1998. Investigations on genotoxic effects of groundwater from the Mitterndorfer Senke and from the vicinity of Wiener Neustadt. Wien Klin Wochenschr 110:824-833.

Koivusalo MT, Jaakkola JJK, Vartiainen T. 1994. Drinking water mutagenicity in past exposure assessment of the studies on drinking water and cancer: application and evaluation in Finland. Environ Res 64:90-101. 
Lefevre F, Audic JM, Ferrand F. 1992. Peracetic acid disinfection of secondary effluents discharged off coastal seawater. Wat Sci Technol 25:155-164.

Loper JC. 1980. Mutagenic effects of organic compounds in drinking water. Mutat Res 76:241-268.

Ma TH, Cabrera GL, Chen R, Gill BS, Sandhu SS, Vandenberg AL, Salamone MF. 1994. Tradescantia micronucleus bioassay. Mutat Res 310:221-230.

Minissi S, Lombi E. 1997. Heavy metal content and mutagenic activity, evaluated by Vicia faba micronucleus test, of Tiber river sediments. Mutat Res 393:17-21.

Minissi S, Caccese D, Passafiume F, Grella A, Ciccotti E, Rizzoni M. 1998. Mutagenicity (micronucleus test in Vicia faba root tips), polycyclic aromatic hydrocarbons and heavy metal content of sediments collected in Tiber river and its tributaries within the urban area of Rome. Mutat Res 420:77-84.

Monarca S, Pasquini R, Scassellati Sforzolini G. 1985. Mutagenicity assessment of different drinking water supplies before and after treatments. Bull Environ Contam Toxicol 34:815-823.

Monarca S, Zanardini A, Feretti D, Dalmiglio A, Falistocco E, Manica P, Nardi G. 1998. Mutagenicity of extracts of lake drinking water treated with different disinfectants in bacterial and plant test. Water Res 32:2689-2695.

Monarca S, Grottolo M, Feretti D, Richardson SD, Thruston AD, Zani C, Navazio G, Ragazzo P, Zerbini I, Alberti A. 2002a. Mutagenicity and disinfection by-products in surface drinking water disinfected with peracetic acid. Environ Toxicol Chem 21:309-318.

Monarca S, Zani C, Rossi C, Buschini A, Poli P, Rizzoni M, Gustavino B, Doerr M, Bolognesi C, Bartoli D, Ciccarelli E. 2002b. Valutazione della genotossicità di acque superficiali sottoposte a disinfezione: prove in vivo (Genotoxicity evaluation of disinfected surface waters: in vivo tests). Acqua Aria 32:75-81.

Monarca S, Zani C, Feretti D, Guzzella L, Rossi C, Poli P, Buschini A, Marabini L, Hrelia P, Richardson SD. 2002c. Genotossicità di acque superficiali sottoposte a disinfezione (Genotoxicity of disinfected surface waters). Acqua Aria 32:88-95.

Monarca S, Rizzoni M, Gustavino B, Casarella S, Alberti A, Feretti D, Zerbini I, Zani C. 2002d. Evaluation of potential genotoxic effects of three drinking water disinfectants using plant tests. Proceedings of the 6th International Symposium on Predictive Oncology \& Intervention Strategies (Cancer Detection and Prevention). Paris, 9-12 February. p S-119.

Rank J, Nielsen MH. 1994. Evaluation of the Allium anaphase-telophase test in relation to genotoxicity screening of industrial wastewater. Mutat Res 312:17-24.

Rizzoni M, Vitagliano E, Marconi MC, Sottili A, Gustavino B. 1987. Micronucleus induction by low doses of X-rays in Vicia faba root tips. Mutat Res 176:205-209.

Rizzoni M, Gustavino B, Ferrari C, Gatti LG, Fano EA. 1995. An integrated approach to the assessment of the environmental quality of the Tiber river in the urban area of Rome: a mutagenesis assay (micronucleus test) and analysis of macrobenthic community structure. Sci Total Environ 162:127-137.

Romero J, Ribo G, Ventura F, Caixach J, Moreno P, Rivera J. 1992. Ames and sister chromatide exchange tests of organic extracts from drinking water. Bull Environ Contam Toxicol 49:259-265.

Rook JJ. 1974. Formation of haloforms during chlorination of natural waters. J Water Treat Examin 23:234-243.

Smaka-Kincl V, Stegnar P, Lovka M, Toman MJ. 1996. The evaluation of waste, surface and ground water quality using the Allium test procedure. Mutat Res 368:171-179.

Tuomisto J, Vartiainen T. 1990. Genotoxicity of drinking waters. IARC Sci Publ 104:307-313.

US EPA (Environmental Protection Agency). 1994. Method 525.2. Determination of organic compounds in drinking water by liquid-solid extraction and capillary column gas chromatography/mass spectrometry. Cincinnati, OH: National Exposure Research Laboratory, Office of Research and Development, US EPA.

Wilcox P, Williamson S. 1986. Mutagenic activity of concentrated drinking water samples. Environ Health Perspect 69:141-149.

Wilcox P, Williamson S, Lodge DC, Bootman J. 1988. Concentrated drinking water extracts, which cause bacterial mutation and chromosome damage in $\mathrm{CHO}$ cells, do not induce sex-linked recessive lethal mutations in Drosophila. Mutagenesis 3:381-387.

WHO (World Health Organization). 1996. Revision of the WHO Guidelines for Drinking Water Quality. Geneva: World Health Organization. 